\title{
CONCILIAÇÃO FRATURADA QUANDO O "ESTUPRADOR" ESTÁ DENTRO DE CASA
}

Everton Rangel ${ }^{1}$

\author{
${ }^{1}$ Programa de Pós-graduação em Antropologia Social, Museu Nacional, \\ Universidade Federal do Rio de Janeiro, RJ, Brasil
}

\section{Introdução}

A pergunta mais abrangente deste artigo é a seguinte: o que implica levar a vida com homens condenados por crimes sexuais para as mulheres que com eles compartem laços afetivos, partilham os dias e trabalham para tornar essa vida viável? Quando iniciei o trabalho de campo em meados de 2015, não imaginava que a relacionalidade (Carsten 2004) assumiria o caráter crítico que ora reivindico para ela. Pensava que, assim como Machado (1998) e Segato (2003), me dedicaria à análise do que dizem os criminosos sexuais. Esse ímpeto não se reproduziu firmemente por um fato bastante objetivo: mães, tias, vizinhas, namoradas, filhas e afins, nas terças-feiras, dia de atendimento de família, lotavam o prédio do Núcleo do Sistema Penitenciário (Nuspen) da Defensoria Pública Estado do Rio de Janeiro (DPERJ) onde as conhecia. Assim como as filas de visitação dos presídios são majoritariamente formadas por mulheres (Lago 2019), as filas das instituições de justiça que se vinculam a esses presídios costumam ser femininas, fato que em si mesmo revela assimetrias de gênero em torno de aspectos como cuidado e/ou lida com a burocracia.

A convivência que venho travando com essas mulheres, bem como com os seus entes queridos, sinaliza a importância de aqui centralizar a discussão em uma análise das relações de gênero em sentido afetivo-moral. Como Segato (2003) e Machado (1998) descreveram o machismo e/ou a dominação 
patriarcal naturalizados pelos seus interlocutores a ponto de estupros serem por eles descaracterizados como violência, busco levar adiante essa constatação descrevendo as assimetrias e as desigualdades das relações de gênero também a partir do modo como as minhas interlocutoras respondiam a elas. Assim, busco descrever como homens e mulheres, mais especialmente elas, no âmbito da intimidade, geriam crimes sexuais que redundaram na condenação de homens que não são quaisquer uns, mas aqueles nos quais são depositadas expectativas relacionais e afetos contraditórios.

Em After Kinship, Janet Carsten (2004) argumenta que uma resposta para a pergunta "o que é ser parente?" depende da ênfase nas emoções, nas práticas morais e no gênero, muito negligenciada pelos estudos clássicos. Essa abordagem requer o conhecimento do trabalho micropolítico desempenhado pelas emoções (Rezende \& Coelho 2010) que possibilitam que a vida seja vivida em ritmo viável nos contextos em que a violência sexual e/ ou a condenação despedaça as pessoas e as relações. O que parentes fazem para não deixar que as suas dores se tornem a totalidade de suas vidas (Das 2018)? A que custo, quando e por que o estupro se torna perdoável? Qual trabalho o silêncio realiza nos almoços de família com o parente reconhecido por alguns como "pedófilo" e por outros como "injustiçado"?

Neste artigo buscarei desenvolver o que chamo de "conciliação fraturada", formas de vida que emergem quando fraturas relacionais existem, mas são remendadas, retorcidas e então novamente costuradas: quando o pai - severamente adoecido - é o violador da filha que, em face do sofrimento dele, se esforça para perdoar o que considera (im)perdoável, e quando almoços de família incluem o tio que é reconhecido pela sua sobrinha como pedófilo, mas por ela é tolerado em função do amor que a irmã dele, mãe dela, sente por seu irmão. Foram inúmeras as vezes em que as minhas interlocutoras me disseram que era "tudo muito complicado" nas relações entre familiares. Para levar a sério essa complicação, recorro à qualificação da ambivalência como fundamento da "conciliação fraturada" e exploro o sentido dessa expressão a partir de dois conjuntos de relações: o primeiro diz respeito a uma leitura da relação entre Lilian ${ }^{1}$ e seu pai Edson - homem que a estuprou - que somente se fez possível no momento em que o adoecimento dele na cadeia foi sentido por Lilian como um chamado à ação; o segundo diz respeito às percepções que a senhora Lurdes e a sua filha Alice nutriam não somente quanto a Ivan, irmão de uma e tio de outra, mas também quanto às formas de gerir estupros que aconteceram dentro das $\operatorname{casas}^{2}$ onde essa família habitava. 
Antes de partir para a descrição dos casos, importa destacar que, como a pesquisa foi realizada a partir do Nuspen, o meu contato inicial com possíveis interlocutoras e/ou interlocutores costumava estar marcado pela percepção de que eu era alguém próximo da defensora pública responsável pelo(s) processo(s) de execução penal ${ }^{3}$ de homens condenados por crimes sexuais que estavam no "final" do cumprimento de suas penas. Ou seja, até certo ponto é possível dizer que, além de me enxergarem como um homem negro, jovem e gay, as pessoas que aparecerão nas páginas seguintes não tendiam a me associar ao ímpeto acusatório próprio da fase de conhecimento ${ }^{4}$ do processo penal e, com frequência, materializado na figura do(a) promotor(a). Contudo, isto não quer dizer que meus (minhas) interlocutores(as) simplesmente me associavam a um sentido genérico de defesa - ajuda, benevolência, confiança em suas narrativas etc. -, até mesmo porque, quanto mais eu me aproximava de seus dramas, mais distante se tornava o ponto institucional de onde parti, mais sinuosas se figuravam as nossas conversas e mais pessoas surgiam sem que soubessem exatamente como eu havia chegado aos seus tecidos relacionais.

A senhora Lurdes, por exemplo, me conheceu na Defensoria, mas logo passou a me chamar de jornalista e, quando conheci a sua filha Alice, esta última disse que chegou a imaginar que eu poderia ser um namorado de sua mãe. Possibilidade posteriormente considerada risível por todos. Embora tenha me sentido confortável para compartilhar com Alice o que eu pensava sobre o seu tio Ivan, nunca me senti desta forma para fazer o mesmo com ele ou com Lurdes. Justamente porque sabia que estava transitando em relações "complicadas", busquei entender o que as pessoas estavam vivendo e/ou diziam sobre o que estavam vivendo, deixando em segundo plano a verbalização dos meus anseios, questionamentos e das minhas dúvidas. ${ }^{5}$ Ao longo deste artigo, faço considerações sobre o modo como fui envolvido pelas relações apenas quando esse envolvimento me permite dizer algo sobre o que estou chamando de conciliação fraturada.

\section{O gosto azedo do cuidado}

Edson assumia que tinha "acariciado" duas de suas filhas e negava ter se envolvido sexualmente com o seu filho mais novo. As confissões dele, mais do que a narrativa de injustiça centrada em um estupro capaz de questionar o desejo heterossexual de um pai violador, me intrigavam. Contudo, foi difícil conversar com ele, pois três aneurismas cerebrais tornaram a sua fala lenta e embaralhada. Ele, por vezes, parecia se desconectar do desenrolar 
dos assuntos, ficando parado, observando, por exemplo, a servidora que no NUSPEN lhe explicava trâmites jurídicos sem obter retorno fluido. "Você está me entendendo, Sr. Edson?", ela perguntava na tentativa de avaliar o grau de compreensão do "assistido" sobre as questões jurídicas apresentadas. O juiz competente havia indeferido o pedido de progressão para o regime aberto devido a um relatório psicológico considerado questionável pela defensora responsável pelo caso em questão. Segundo ela, não seria legítimo vetar a Edson a possibilidade do cumprimento de pena em casa em função de uma recomendação de tratamento terapêutico por um ano fora do sistema penal, condição a ser cumprida antes que o próprio pleito de progressão voltasse a ser instaurado pela Defensoria. A psicóloga que realizou tal recomendação concluiu o seguinte: "a força da lei do Estado vem sendo um instrumento de grande valia para que Sr. Edson respeite as leis referentes à expressão da sexualidade na sociedade".

Nas poucas vezes em que consegui conversar com o Edson, o corpo que ele sentia definhar era narrado via pedidos de ajuda que deixavam pouco espaço para o passado. A urgência dos seus clamores jogava para as bordas as falas sobre a saia curta da adolescente que, mesmo sendo a sua filha, provocava-o sexualmente; a árvore onde ela subia sem calcinha quando criança; a ex-mulher que teria mentido sobre o processo "do menino"; o não reconhecimento do desejo sexual pelo filho; a altercação entre falas suavizadas como "toquei nas meninas" e escorregadias como "a Justiça diz que estuprei as minhas filhas". A violência sexual somente não era minada pelo sofrimento sentido por Edson porque eu continuava perguntando: "e aí?"; "o que aconteceu?"; "eu não entendi!"; "onde ficava essa árvore?"; "em que momento isso aconteceu?". Ao passo que a posição de inquiridor se revelava a mim, o meu silêncio começava a preponderar e mais espaço o corpo adoentado angariava. Ao mesmo tempo em que a violência era expressada através de palavras eufemísticas, toques apresentados como não excessivos, sobressaltava-se a proximidade da morte física do pai violador. Para dar carnadura a essas colocações, listo duas frases ditas por ele:

Eu me perco no prédio onde trabalho. Eu caio em cima dos outros, ando esbarrando, está difícil trabalhar. Não faz sentido falar sobre algo que aconteceu 20 anos atrás. É como um cachorro que volta ao vômito, é como tomar banho e depois tomar outro (Edson, entrevista realizada em 2016).

No relatório psicológico, Edson é descrito como um homem incapaz de analisar criticamente os estupros que cometeu. Não sente culpa. A astúcia dele é demarcada em frases taxativas como "parece repetir um texto ensaiado" e "em diversos momentos da entrevista mostrou ter conhecimento 
sobre o conteúdo do relatório anterior e buscou dar respostas refletidas e cuidadosas". É notável que o Edson materializado no documento produzido poucos meses antes de eu o conhecer difira do "assistido" que, sentado em frente a mim, tinha dificuldade até para contar que demorou a chegar no Nuspen porque, no meio do caminho, esqueceu para onde ia. Os lapsos de memória que sensibilizavam a servidora e a mim foram qualificados pela psicóloga como "falta de disposição" do "paciente" em procurar assistência médica. A força da declaração da especialista "psi" questionava a autenticidade do sofrimento, bem como responsabilizava o meu interlocutor pela sua condição de saúde. É verdade também que a força do relatório, conforme os dias passavam, ganhava concretude especial. Em um presídio de regime semiaberto, Edson ficava cada vez mais doente e, por conseguinte, mais dependente de terceiros. A presença de Lilian na Defensoria se fez nesse contexto. Ela foi uma das poucas pessoas, dentre os parentes dele, que se dispôs a intervir contrariamente ao relatório em questão.

Lilian estava entregando comprovantes de residência quando a vi. Estranhei a presença dela na Defensoria, acoplada à ausência de Edson, porque ele era um dos muitos "assistidos" que, semana após semana, ia checar a concessão de "benefícios" e, em geral, frustrar-se com a lentidão dos procedimentos, com os indeferimentos de pedidos e a pendência quase contínua de documentos. Demorei um pouco para descobrir que Lilian era filha desse homem e mais ainda para supor que ela, quando criança, poderia ter sido a vítima de um dos processos que culminaram na prisão dele. Considerando que ela tinha 30 e poucos anos, poderia ser que, entre a acusação realizada em sede policial e o curso do processo penal, mais ou menos duas décadas tivessem passado. Iniciei a conversa com Lilian numa cafeteria em rua próxima à sala de atendimento onde vítimas de estupro não costumavam adentrar, explicando como conheci Edson. O constrangimento, alimentado pela lógica da confidencialidade que regulava o que eu poderia dizer sobre o que o seu pai havia me dito, me levou a usar o termo processo. "Sei que o seu pai respondeu a três processos", disse. Ela enumerou: "é, tem o meu, o da minha irmã e o do meu irmão". Evitávamos acionar a palavra estupro. "O que ele fez comigo" era a expressão mais marcante que minha interlocutora utilizava para instaurar na linguagem a violência sexual cometida por seu pai. O que ele fez com ela é uma vastidão de acontecimentos espraiados no tempo e no espaço, porém reunidos no corpo que ali estava e narrava o que viveu.

A tal árvore em que Lilian nunca subira quando criança; o dia da festa de 15 anos em que ficou bêbada e custou a angariar força para mandar ele parar; os momentos em que, até os 10 anos, foi acordada e tocada; 
o período em que ele parou; o ano em que tinha 6 anos de idade, marco de quando tudo começou; a falta de credibilidade atribuída pelos tios a ela; as ameaças do pai; a possibilidade de apanhar; os lugares em que apanhou; o medo de não ser amada; as casas nas quais viveu e foi estuprada. Cada cena brotando de jeito manso e sendo entrecruzada por menções aos filhos, à mãe, à madrasta e ao marido, que sabe de tudo o que aconteceu e a entende. Lilian dizia que não sabia exatamente o que o seu pai tinha feito com a sua irmã, mas que sabia que algo tinha acontecido. Em relação ao seu irmão, desconfiava. Achava que a sua madrasta poderia ter forjado a acusação. Dolores era mãe de Beto e Duda, crianças nascidas no segundo casamento de Edson. Foi o processo de Duda que fez com que o de Lilian, arrastado por muitos anos, andasse. Já o de Beto, igualmente concluído com a sentença condenatória, poderia ser fruto da maldade de Dolores. À medida que essas pessoas iam aparecendo, a relação complicada com a madrasta ganhava densidade. Dolores tratava Lilian como empregada, reclamava da comida por ela preparada e não gostava que a sua enteada usasse roupas que chamassem a atenção dos homens, sobretudo do seu pai. A madrasta ora cuidava de Lilian, evitando a exposição dela ao perigo trazido por Edson, ora desejava se posicionar como objeto do desejo masculino.

Contando sobre o quanto era humilhada por não saber preparar um bom fígado, Lilian demarcou que a sua mãe, pessoa que nunca lhe ensinou a cozinhar, preferiu o padrasto a ela. Como resultado da preferência materna que a magoou, Lilian, ainda adolescente, foi morar com Dolores e seu pai. Ela permaneceu na casa onde era maltratada, mesmo depois que Edson foi pego por Dolores tocando a filha do casal. A figura da madrasta má, ancorada no trabalho não reconhecido e em disputas sobre quem poderia ser bela, se dava também a partir de bebedeiras, incorporações de santos, discussões virulentas e da desconfiança de que Edson, mesmo depois das acusações de estupro, seguia sendo desejado afetivo-sexualmente. Lilian me deu a entender que não se surpreenderia se Dolores assumisse que, vez ou outra, transou com Edson no curso dos três processos. A conjugalidade alegadamente desfeita em razão dos estupros havia, em momento anterior, sobrevivido às pancadarias constantes. Era esse conhecimento que fazia a filha de Edson suspeitar da sua madrasta, como se o desejo sexual fosse uma força presente nos conflitos de outrora e resistisse como uma dúvida que assombrava na medida em que revelava o factível, o possível, aquilo que não se sabia com certeza, mas existia enquanto conhecimento incorporado. O desconforto gerado em Lilian pela relação afetivo-sexual de Dolores com Edson era evidente. 
Advirto, porém, que era sobretudo como mãe que minha interlocutora se colocava narrativamente em oposição à sua madrasta e à sua genitora. Lilian cuidava. Não trocaria os seus filhos por homem nenhum, nem desejaria o corpo proibido de um pai violador. Ela cuidava dos seus filhos e daqueles que não eram seus, e sim de uma prima que, devido ao alcoolismo, perdeu a guarda das crianças. Cuidava ainda do seu padrasto, desde que a mãe dela morrera e ele ficara sem ter quem lhe preparasse comida. Se, por um lado, Lilian idealizava o cuidado como prática ética que lhe permitia ser uma boa mãe, por outro lado, ela evidenciava como o cuidado e a violência não são termos antagônicos, e sim práticas que se imiscuem nas relações que não encontram resolução fácil. Lilian dava de comer ao seu padrasto e não abdicava do ressentimento que nutria em relação a ele e à sua mãe. Longe de querer assim adotar o ponto de vista normativo segundo o qual o ressentimento é um sentimento a ser abandonado, aponto, como sugere Caduff (2019), que o cuidado pode ser menos generoso do que parece e implicar uma série de sentimentos contraditórios, de tal modo que é possível até mesmo cuidar sem se importar de fato com a pessoa que demanda cuidado, ou seja, é porque a afeição não é condição sine qua non para o cuidado que o próprio ato de cuidar exige cuidado.

A capacidade de Lilian de habitar um tecido relacional dedicando-se continuamente às pessoas que a feriram, não reconheceram o bem-fazer atuado e a violentaram de maneiras múltiplas e sobrepostas adveio da conversão ao budismo. Desde os 14 anos, idade em que tentou se suicidar pela primeira vez, ela frequenta os templos. Neles, aprendeu sobre o carma e pôde reler a sua vida a partir desse prisma. O que sofreu poderia ser fruto de outras encarnações. Talvez Edson tivesse vindo como seu pai para que Lilian enfrentasse quem foi e o que fez em outras vidas. "Eu acho que tenho carma com os homens", disse ela pensando naqueles aos quais amou e dos quais cuidou. Um namorado a abandonou em função de conflitos familiares. O pai bateu em outro, que acabou terminando a relação. O primeiro marido se drogava e sumia. O atual, que é uma boa pessoa e a entende, já teve as suas incursões pela violência. O padrasto roubou o amor da mãe. E o pai fez o que fez.

O carma, no plano ordinário, é uma linguagem espiritual que explica o mal e descreve as relações de gênero como profundamente violentas. Uma vez que pensava o carma através das relações em que habitava, Lilian convertia uma categoria religiosa em uma linguagem generificada do mal causado pelos homens, mas também pelas mulheres a eles vinculadas. As práticas de cuidado às quais Lilian se devotava não devem, portanto, ser separadas da forma como ela entendia e vivia o budismo, pois, praticando 
o cuidado, ela acreditava cultivar carma positivo: afastava-se do mal, realizava-se como boa mãe e dedicava-se a si mesma. Em resumo, a crença no carma auxiliava os passos da filha de Edson em direção à Defensoria, local onde ela fazia algo que considerava bom para o seu pai, definia uma forma de culpabilizar a si mesma por opressões, desigualdades e violências e, sobretudo, sustentava a capacidade de seguir suportando o gosto azedo do trabalho emocional ao qual ela se devotava.

Lilian me disse que levou muito tempo para conseguir encontrar um ponto a partir do qual pudesse avaliar a sua vida com algum distanciamento e, principalmente, enxergar o seu pai. Ela sugeriu que eu pensasse em uma peça de teatro para que pudesse compreender a existência da multiplicidade de pontos de vista. "Tem o olhar do diretor, tem o olhar da pessoa que está atuando como atriz, tem o olhar do público". Mas o que ela queria que eu de fato entendesse era a busca por uma perspectiva que pudesse oferecer acalanto ao seu sofrimento: "é necessário a gente enxergar de fora porque senão a gente fica se vitimizando o tempo todo. E dali você não sai. Uma situação-problema que você tenha. Está ali sofrendo. Você não consegue se projetar fora dali. Está ali, ali, ali". Lilian questionava a sua posição enquanto vítima para que pudesse ejetar-se da temporalidade e da geografia do estupro, ainda que seguisse lidando com feridas subjetivas não cicatrizadas. Agir em nome de Edson - dele cuidar colocando-se como filha contrária ao relatório psicológico - requeria antes de mais nada que Lilian fosse capaz de suportá-lo e, novamente de acordo com ela, de perdoá-lo: "eu achava que tinha perdoado, mas eu não tinha perdoado, porque eu não conseguia conviver com ele. [...] Eu não queria ver a cara dele".

O perdão que minha interlocutora tentava fomentar em relação a seu pai fora enunciado a mim na iminência da morte dele, em face das debilidades motoras e neurológicas que diziam que a punição estatal, ao contrário do que pensava a psicóloga, precisava ser estancada. A meu ver, a cadeia regulava a expressão da sexualidade de Edson, em menor grau transformando a maneira como ele enxergava os seus filhos e em maior grau matando-o lentamente. E essa morte não era um carma que Lilian quisesse para si. A morte é criadora de processos de socialidade, uma vez anunciada, ela organiza os afetos (Elias 2001). Não qualquer morte, mas a de um pai em situação de extrema vulnerabilidade. O mal morrer gera efeitos sobre os sujeitos, sendo um deles a compaixão que hierarquiza os saudáveis e os moribundos e que opera como um chamado à ação. Esse chamado pode ser ignorado, ou ser respondido de modo breve e pouco comprometido, ou ainda, como no caso de Lilian, transformar-se de fato em um curso de ação marcado tanto pelas práticas azedas de cuidado quanto pela busca pelo perdão. 


\section{O perdão (im)possível é o perdão tentado}

Deixarei de lado as exegeses de cunho histórico e a análise dos vínculos entre tradições religiosas e seculares no que se refere ao perdão porque tais empreendimentos já foram desdobrados por uma série de autores (Derrida 2005; Margalit 2004; Griswold 2007). Minha intenção é a de considerar apenas as formulações que me permitem, parcialmente, visualizar o que vivia Lilian. O primeiro apontamento digno de nota é o de que a imagem do perdão que ela evocava dividia-se entre o conceito cristão de perdão incondicional - aquele que excede toda troca, todo pedido de arrependimento como retribuição, toda exigência de transformação do pecador, toda finalidade de cunho psicológico, terapêutico e político - e o conceito, igualmente cristão, de perdão condicional (Derrida 2005). Este segundo tipo de perdão, ao abdicar de se realizar como amor sem fim e sem cálculo - quanto mais amor, mais perdão, pois quem pouco perdoa pouco ama -, demanda, segundo os autores já citados, uma resposta do ofensor ao ato benevolente. Que resposta é esta quando o perpetrador é um pai que, se reconhecia a violação que causou, não deixava de culpabilizar a própria vítima? Para colocar o que nos conta Lilian no centro da análise das especulações filosóficas sobre o perdão, parto desta pergunta crucial.

Como muitas vezes o perdão é pensado como uma resposta a um dano que exige daquele que o causou um retorno apropriado, a lógica da dádiva termina em certas análises operando como um preceito ético. Margalit (2004) chega a propor que a obrigatoriedade de retribuir o remorso sincero do ofensor com o perdão assemelha-se ao caráter compulsório da troca de presentes. Neste caso, estaria em jogo não tanto a produção de relações através da troca, mas, sobretudo, a restauração das relações que já existiam em momento anterior ao dano. Weitz (2005) bem sugere que a análise de Margalit concentra-se demasiadamente na parte injuriada. Foca nos sentimentos e nas atitudes que os ofendidos estariam impelidos a superar, como o desejo de vingança e o ressentimento, mas não aborda de modo convincente o papel do remorso no processo de dar, receber e retribuir.

Pensando no caso de Lilian e Edson, temos, por um lado, uma ofendida que se esforça em dar ao ofensor um perdão que não lhe foi pedido diretamente e, por outro lado, um ofensor que não retribui plenamente as expectativas sociais de demonstração de culpa, remorso etc. Esse quadro revela a possibilidade de o corpo em processo de morte ser ele mesmo uma resposta ao trabalho emocional executado por Lilian. Não estou dizendo que minha interlocutora queria ver o seu pai morto, bem ao contrário, pois a proximidade da sua morte acentuava a busca pelo perdão, sentimento 
condicionado a um cálculo que, por mais impreciso que fosse, resultava na identificação do excesso da pretensão punitiva estatal. Dito de outro modo, a punição gerava uma demanda por perdão como alternativa ao fazer morrer e ao carma proveniente desse fazer. O corpo do pai - meio vivo, meio morto - é uma resposta à vítima que comporta um clamor por ajuda e, em tom menor, porém audível, uma acusação de responsabilidade.

Se o perdão demanda reciprocidade nas relações interpessoais, a reciprocidade pode ser forjada de maneiras inusitadas, sem eliminar as assimetrias da troca entre ofensor e ofendido, nem quitar o ressentimento de quem tanto sofreu e, ainda assim, seguia sentindo-se impelida a tentar fazer viver. Deve ficar claro que levar o ofensor à miséria pode não aliviar as dores do ofendido e pode resultar em autorresponsabilização, seja através do sentimento de culpa, seja através da linguagem do carma. Nesse sentido, é adequado pensar que o perdão que Lilian buscava tinha a ver com a interrupção de um ciclo de vingança que a ultrapassava na medida em que perpassava as práticas estatais. Como se ela estivesse me dizendo: não sou eu, é o Estado que está matando o meu pai e foi ele que fez por terminar na prisão. E inevitavelmente estivesse, mais do que perguntando a si mesma, tentando fazer alguma coisa em relação ao que sentia e em nome do pai. Se a vingança é o maior abuso do ressentimento (Griswold 2007), é certo dizer que Lilian renunciava à vingança moderando o seu próprio ressentimento, buscando controlar os malefícios causados pelo excesso punitivo e, no limite, tentando perdoar. É sobretudo a esse empenho custoso, dolorido e necessariamente repetitivo que estou chamando de trabalho emocional. Diz Hochschild (2013):

Por "trabalho emocional" refiro-me ao ato de tentar mudar, em grau ou qualidade, uma emoção ou sentimento. "Trabalhar" uma emoção ou sentimento é, para os nossos propósitos, o mesmo que "gerenciar" uma emoção ou realizar uma "atuação profunda". É importante assinalar que "trabalho emocional" se refere ao esforço - ao ato de tentar - e não ao resultado, que pode ou não ser bem sucedido. Atos fracassados de gerenciamento também indicam quais formulações ideais orientaram o esforço e, por isso, não são menos interessantes do que o gerenciamento emocional que dá certo. A própria noção de tentativa sugere um posicionamento ativo diante do sentimento (Hochschild 2013:185).

Assim, a autora chama a atenção para a possibilidade de o trabalho emocional tornar-se uma atividade consciente nos casos em que os sentimentos de uma pessoa não combinam com a avaliação que ela faz de uma dada situação e dos sentimentos que seriam mais apropriados de serem sentidos. Esse processo de acentuação reflexiva foi vivido por Lilian conforme 
ela avaliou a situação em que seu pai se encontrava e identificou e idealizou o perdão como resposta à produção estatal da morte. Para ser mais fiel ao vocabulário de Hochschild, saliento que a minha interlocutora realizava um trabalho emocional de duplo sentido: tanto "evocava" um sentimento desejado, o perdão, quanto se esforçava para "suprimir" um sentimento indesejado, o ressentimento. Nesse sentido, entendo que a evocação do perdão era uma tentativa de produção da conciliação entre pai e filha e que a supressão do ressentimento mais parecia um movimento em direção a um objetivo não alcançado, sempre um pouco mais além. A centralidade da ideia de tentativa me permite apontar para a qualidade muitas vezes inconclusiva do trabalho emocional, do querer sentir diferente, algo pelo qual Lilian batalhava, mas que também a prendia, agarrava, não soltava - como se o próprio ato de tentar fosse pegajoso. Como ela estava tentando sempre e de novo, proponho que a conciliação sobre a qual falo estava decididamente fraturada, destinada a se romper, a ser refeita e a se romper uma vez mais durante o processo de restauração do tecido relacional em questão.

Durante um tempo, eu fiquei assim... Lembrava e ficava com raiva do meu pai e não queria falar com ele. Mas, assim, o que mais me doeu foi a relação de confiança... é... traída, né? Porque um pai, para a gente, é o quê? É um herói. É a pessoa que está ali para te proteger, e não para fazer uso da confiança que ele tem do filho para abusar do filho, entendeu? Então, isso é o que me doeu mais. É o meu pai não ter tido esse senso. Isso que doeu mais em mim (Lilian, entrevista realizada em 2017).

Costumava me perguntar se o trabalho emocional que Lilian executava e que a envolvia impiedosamente era um movimento em direção ao luto, dada a atribuição de valor negativo ao ressentimento, à evocação do perdão e à proximidade da morte do pai. Contudo, menos do que determinar a direção precisa para onde seguiam os sentimentos da minha interlocutora, algo que redundaria em um exercício de futurologia, importa aqui aventar a possibilidade do querer sentir diferente, tal como ela tentava, ser uma forma de enquadrar a memória, buscando fazer repercutir lembranças sobre o pai não marcadas pelo estupro.

Lilian nunca me disse coisas positivas sobre Edson, mas me falava sobre o herói que ele nunca fora, como se quisesse que ele o tivesse sido. Certamente precisaria conhecer mais para ir além da sugestão de que as lembranças que Lilian quereria encontrar, até mesmo para sustentar a evocação contínua do perdão, pareciam não existir - ou não existiam ainda. O que havia nas nossas conversas era uma ideia de paternidade heroica que operava como um enquadramento e uma base para a tentativa de 
produzir alguma memória positiva sobre o pai violador. Se, por um lado, os simbolismos podem ser cruéis ao provocarem engajamentos que dilaceram os sujeitos, por outro, a memória não conhece caminhos fixos, pois está em constante movimento e responde às urgências do presente. Quero assim dizer que não havia como saber se o trabalho emocional a que Lilian se dedicava se expandiria para as direções que apontava, se redundaria em luto e não melancolia ${ }^{6}$ (Freud 2011; Butler 2004); afinal, os caminhos que ela estava trilhando para produzir alguma lembrança positiva produziam dores que podiam terminar estancando o querer sentir diferente e levando para outra forma de relação com o pai depois da sua morte.

Se o nosso relacionamento com o passado está sempre suscetível a mudanças, ainda que muitas vezes nos apeguemos a certos enquadramentos a que ele está sujeito, a memória "nunca está fora do tempo" e nem é "pragmaticamente neutra" (Lambek 1996:240). Lembrar, deste ângulo, é estabelecer uma relação moral com aquilo ou com a pessoa que está sob julgamento, pois "o valor da articulação de versões específicas do passado está conectado às suas finalidades morais e às suas consequências para as relações no presente" (Lambek 1996:239). Dizer que a maneira como as pessoas vivem as suas memórias gera implicações para a maneira como elas atualmente veem aqueles com os quais se relacionam é o mesmo que dizer que as memórias são práticas morais, elaborações simbólicas do passado que os sujeitos organizam discursivamente e incidem sobre o presente de maneiras diversas. Estou chamando a atenção para as circunstâncias atuais, os compromissos subjetivos, as dinâmicas das relações e as invenções do passado porque a fratura na relação entre Lilian e seu pai derivava dos estupros que ela sofrera e se atualizava constantemente através do próprio movimento de restauração do laço afetado pelas violências. Podemos imaginar que quanto maior o esforço dela para juntar tudo o que foi corroído, mais e novos fragmentos relacionais se deterioravam e mais e novos esforços eram exigidos. Nesse sentido, a fratura é parte inseparável do ato de tentar se conciliar com um pai que fez o que fez, é parte da vida daquela para quem uma recuperação total talvez não seja possível.

O perdão deve então tampar o buraco? Deve suturar uma ferida em um processo de reconciliação? O bem dar lugar a outra paz, sem esquecimento, sem anistia, fusão ou confusão? Por suposto, ninguém se atreveria decentemente a objetar o imperativo da reconciliação. É melhor pôr fim aos crimes e às discórdias. Mas, uma vez mais, creio que temos que distinguir entre o perdão e o processo de reconciliação, esta reconstituição de uma saúde ou de uma "normalidade", 
por mais necessárias e desejáveis que possam parecer através de amnésias, do trabalho de luto etc. Um perdão "finalizado" não é um perdão, é somente uma estratégia política ou uma economia psicoterapêutica (Derrida 2003:29). ${ }^{7}$

Para elucidar o modo como penso a ideia de conciliação fraturada, perpasso agora algumas colocações de Derrida (2003) que me parecem de extrema valia. O argumento que mais me interessa é o de que o "perdão puro" apresenta-se como o impossível, na medida em que se move sempre na direção do imperdoável. Quando uma declaração de perdão acontece, já não estamos lidando com o impossível, mas somente com aquilo que é passível de conciliação e, portanto, já encontrou alguma outra linguagem para a sua realização: luto, alívio, anistia, esquecimento, qualquer que seja o termo utilizado para definir negociações entre sujeitos em posições assimétricas e emoções vinculadas às relações densas e/ou violentas. Isto não quer dizer que a ideia de conciliação não seja objeto de valor social, ou que crimes e práticas de violência devam ser legitimados, e sim que o perdão puro é louco. Trata-se de uma loucura do impossível. O perdão puro, que também podemos chamar de incondicional, é estranho a qualquer justiça. Não conhece critérios, desafia linguagens, ignora as matemáticas afetivomorais, quando não as ordens jurídicas, que insistem em contabilizar os danos sofridos e que, com base nessa contabilização, estabelecem ou não linguagens, parâmetros e estratégias de compensação. A loucura à qual Derrida se refere tem a ver com a gratuidade de um perdão que, se replica o amor infinito de Deus, tende a esbarrar com as demandas por performances de arrependimento nos meandros da vida ordinária e as formas de regulação estatal do dano e sua compensação.

O autor, apontando e questionando os limites das elaborações estatais do perdão, sugere a existência de processos geopolíticos que abusam desse sentimento. Para descrever esse abuso, ele utiliza inclusive trechos do depoimento uma mulher na Comissão de Verdade e Reconciliação da África do Sul. Disse ela: "uma comissão ou um governo não pode perdoar. Somente eu, eventualmente, poderia fazê-lo. (And I am not ready to forgive). E não estou disposta a perdoar - ou pronta para perdoar" (Derrida 2003:22-23). ${ }^{8}$ Para os meus propósitos, basta dizer que para Derrida o perdão implica uma relação única entre a vítima e aquele que a vitimou e somente ela pode decidir ou não perdoar. A presença de um terceiro - o Estado - interessado no perdão seria uma intrusão de critérios de justiça no interior de um conceito que em seu estado puro não conhece nenhum sentido de justiça. A incondicionalidade do perdão escaparia ao Estado e à própria vida ordinária, pois, uma vez baixada do plano ideal em que se realizaria como 
loucura, adentraria no plano do possível, do negociável, da busca por uma linguagem de pacificação social ou controle de tensões. O paradoxo seria então que o perdão puro somente encontra sentido não tendo sentido algum, não sendo inteligível, visto que, quando alguém começa a perdoar, o perdão condicional toma a cena. Nota-se, assim, que a figura do terceiro, o mediador, está associada nessas formulações à espécie impureza da vida ordinária.

O perdão condicional e o perdão incondicional seriam tão irreconciliáveis quanto indissociáveis. O primeiro, para existir como tal, dependeria de uma idealização do segundo, isto é, uma certa imagem do imperdoável regularia o perdão possível e se infiltraria na maquinaria estatal. E o perdão puro seria uma loucura da qual as linguagens jurídicas e políticas não poderiam e nem conseguiriam se apropriar completamente, pois comportaria um tipo de enigma indecifrável, mistério ou segredo incompreensível. Derrida (2003) chega a enxergar a si mesmo como dividido entre estas duas dimensões do perdão, senso que não é exclusividade sua. Diria que Lilian encontrava-se diante do mesmo dilema quando tentava perdoar o imperdoável e, nesse movimento, terminava tornando o imperdoável sempre um pouco mais perdoável. A questão é que, enquanto o autor quer conservar distinções que lhe parecem importantes de serem compreendidas como radicais, minha interlocutora aproximava de maneira bastante dolorosa o impossível de ser perdoado do possível.

Quero privilegiar esta segunda forma de lidar com ordens irreconciliáveis, porém indissociáveis, porque ela bem caracteriza isto que estou chamando de conciliação fraturada: um perdão impossível que, ao ser tentado, criava alguma chance de aproximação entre pai e filha, mesmo sem quitar o ressentimento causado por estupros que se repetiram no tempo. A perduração deste sentimento nos permite ver o estupro como um dano que não termina de cicatrizar, ainda que se aprenda a viver com ele. O meu interesse nas formulações de Derrida deriva da possibilidade de sugerir que o Estado, nos termos da história de Lilian e Edson aqui descrita, aparece primeiro como aparato produtor da morte do pai e depois como aparato que, ao projetar sobre os ombros de Lilian um corpo nem vivo, nem morto, demanda de maneira obscena o perdão impossível. Este caso é crítico para a minha argumentação porque se situa no ponto onde o perdão impossível desce ao ordinário e, exatamente a partir desse movimento, promove uma saída conciliatória. As fraturas relacionais e subjetivas são parte inseparável desse processo de tentar e tentar de novo transformar o impossível em possível. 


\section{Estupro e transmissões entre gerações}

Reconhecido anteriormente o papel da memória na construção e na sedimentação das relações, gostaria de começar a pensar a noção de conciliação fraturada tanto a partir das diferentes percepções que as pessoas que habitam um mesmo tecido relacional podem ter sobre homens condenados por estupro quanto a partir das transmissões transgeracionais de formas de lidar com o acontecimento da violência sexual no seio de uma família. Quando Lambek (1996) argumenta que a memória é uma prática moral, ele está pensando que as narrativas são veículos da memória. Nesse sentido, antes de ser individual, a memória é intersubjetiva. Grace Cho (2008) é uma das autoras que, a meu ver, melhor descrevem o modo como a intersubjetividade pode nos assombrar. Sua análise é particularmente importante aqui porque difere da ênfase de Lambek na qualidade pragmática do relembrar e centra-se nos conteúdos não elaborados da experiência, porém inconscientemente insinuados na conduta dos sujeitos e transmitidos de uma geração a outra. Cho usa a imagem impalpável do vento para nos contar sobre a repercussão do trauma vivido por sua mãe na geração da autora, filha que viveu os efeitos da diáspora coreana na casa em que cresceu. Parto da noção de trauma porque, contornando-a, espero reconhecer algumas das suas potencialidades e alguns dos seus limites no que tange à compreensão das transmissões geracionais.

A diferença entre a família de Grace Cho e a de seus vizinhos norteamericanos revelou-se cedo para ela, ainda que sua mãe se recusasse a falar sobre o que constituía essa diferença. Através da qualidade ativa do silêncio, fomentava-se a reprodução transgeracional do trauma, isto é, a recusa em falar sobre a vida anterior ao casamento com um soldado americano contava sobre o assombro que a figura da noiva de guerra, aquela constituída a partir de estupros, mortes e assimetrias, produzia na intimidade das relações familiares. O efeito do assombro é produzido não exatamente pelo trauma original, o da guerra, e sim pelo silêncio em torno dele. Os silêncios transportam os ventos infelizes, veiculam o que não é permitido que uma geração conte a outra através das palavras.

Sem fazer justiça à enorme capacidade de Cho em articular planos de análise distintos, o dos acontecimentos que marcam as memórias das nações e o dos acontecimentos que marcam as pessoas e as famílias, destaco uma pergunta: "que lugar melhor para enterrar um trauma social do que no espaço bem guardado da família?" (Cho 2008:14). ${ }^{9}$ Acredito que esta pergunta na análise da autora fomenta uma descrição dos custos da guerra para as famílias, o que é relevante, nevrálgico, porém distante dos meus 
dados empíricos. O meu interesse nela tem mais a ver com a oposição entre a representação da família como espaço traumatizante e a sua representação como espaço harmônico - ambos os discursos, sabemos, são acionados com frequência, por motivos éticos e políticos diferentes e por atores distintos em contextos variados. Menos do que advogar a favor ou contrariamente a cada uma dessas representações, o meu objetivo é eclipsá-las com a ideia de conciliação fraturada, algo que somente pode existir no ponto onde os tormentos da vida encontram algum abrandamento, mesmo que muito custoso.

Enquanto Cho enfatiza o trauma como conteúdo psicossocial móvel, Duarte (2011) apela para uma categoria que, derivando também de um fundo psicanalítico, não parece comprometida a priori com a ideia de efeito negativo transmitido de geração a geração. Sendo "uma configuração imaginária projetiva que é transmitida aos descendentes (ou a alguns deles) de um modo não completamente explícito ou consciente" (Duarte 2011:16), o "mandato" caracteriza um conteúdo cujo sentido moral não está contido na própria palavra que designa o processo de transmissão. Há algo arbitrário na ideia de mandato que me interessa, pois, para além dessa ambivalência valorativa a que me reportei, ele pode ser radicalmente recusado pelos sujeitos, uma vez que podem existir condições materiais, simbólicas e psicológicas que impossibilitam que uma demanda herdada seja atendida. Estou buscando chamar a atenção para dois problemas vinculados: (1) a questão do valor moral daquilo que é passível de ser transmitido de uma geração a outra; (2) a possibilidade de reprodução de um conteúdo psicossocial falhar em um registro da vida, mas bem fluir em outro registro.

Teço essas considerações lembrando que o termo "trauma" foi utilizado por Alice, filha da senhora Lurdes, com o intuito de qualificar negativamente a forma como a sua mãe e outros parentes lidavam com os estupros cometidos pelo seu tio Ivan contra a própria filha e uma das irmãs dele, a única com "problemas psicológicos". Faço referência a esta palavra porque é preciso atentar para o que ela quer dizer ao ser moralmente utilizada, isto é, ao ser descrita como "dificuldade de admitir o óbvio". O trauma é nesse sentido uma impossibilidade de verbalizar a violência sexual que, ao não ser reproduzida por Alice e suas primas, tornava-as diferentes dos parentes da geração anterior que negavam e/ou silenciavam os estupros cometidos por Ivan. Refiro-me a Lurdes, sobretudo. Selecionei dois trechos de uma entrevista que realizei com Alice que me permitem desdobrar a questão da reprodução inexata do mandato de silenciamento pela geração mais jovem e ir além do enquadramento da geração mais velha como traumatizada. 
É esse o ponto. Eu acho que tem gente da minha família que acredita muito nele [Ivan] e tem gente que não quer enxergar a verdade, não quer assumir que você tem uma pessoa com problemas psicológicos que levam a abusar de crianças, um pedófilo na família. É uma parada que a minha família nunca vai admitir, de jeito nenhum. Então, eu acho que a minha mãe é uma delas... Ela acha que o tempo que ele ficou preso serviu para ele mudar porque ele se converteu, aceitou Jesus e não sei o que e não sei o que lá. E meio que zerou o passado dele. Eu no fundo acho que a minha mãe sabe que é verdade. Só que nunca vai assumir. É o irmão dela, o irmão dela se regenerou, então...

É o que te falei. Se você conversar com todos os meus tios, eu acho que se você conseguir cavar ali, você tira deles que todo mundo acredita que sim, só que ninguém nunca vai assumir, sabe? Meus primos, não. Tipo, eu e minhas primas a gente fala abertamente o que a gente acha que aconteceu, e acabou. Mas, tipo, a gente já conversou uma vez entre a gente. Acho que quando ele estava para ser solto e tudo mais. Nesse processo aí. E aí, a gente conversou... Temos a mesma linha de raciocínio? Sim, temos. A gente vai falar sobre isso com o resto da família? Não, porque nego vai bater na gente (Alice, em entrevista em 2018).

Os dois trechos sinalizam que Lurdes abafava as discussões sobre estupros no seio familiar que indicassem a culpabilidade de Ivan e, ao mesmo tempo, focava na sua regeneração espiritual e moral. Deste ângulo, a incapacidade de admitir a violência sexual está vinculada não a um trauma derivado do passado, mas sim a uma demanda do presente em que a conversão religiosa ${ }^{10}$ preponderava. Era perceptível o incômodo que o discurso religioso de Lurdes gerava em Alice, pois ela não aceitava, por exemplo, que Ivan fosse comparado a um personagem bíblico chamado Jonas, profeta que, tal como Ivan, teria clamado pelo perdão divino após ter se arrependido dos erros que cometera. Questionar e não aceitar são aqui formas não radicais de contraposição ao que era representado como obscurantismo religioso. Alice contrapunha-se bufando. Talvez tenha ido além deste gesto em outros momentos, o que não soube e nem presenciei. Ela bufou inclusive quando lhe perguntei se, como a sua mãe era evangélica, conheceria a história de Jonas. Uma vez que Lurdes argumentava que seu irmão fora injustamente condenado, os pecados aos quais ela se referia eram outros que não os estupros: bebedeiras, jogatina e mulheres. Ivan seria Jonas porque, teimosos, ambos insistiram em não seguir a Palavra e, por isso, terminaram disciplinados por Deus através de punições aptas a gerar abnegação e obediência, estados de espírito que seriam indispensáveis à misericórdia como recompensa divina. 
Calando-se, Alice facultava os almoços de família. Foi o marido dela quem lhe ensinou a escutar e a abstrair as colocações religiosas, mas não somente estas. Em uma dessas ocasiões de comensalidade, a única em que estive presente, o filho dela perguntou: "mamãe, o que é pedofilia?". Sentados à mesa, estávamos eu, ela, sua irmã, seu marido, seu tio e sua mãe. A criança estava brincando sozinha próxima de todos, mas tenho a impressão de que somente eu vi quando Alice, que estava perto dele, estendeu os braços e tapou-lhe a boca. O rosto dela expressava um sorriso debochado, um tanto contido, feição que me lembrava o seu jeito meio irônico de colocar-se diante de sua mãe e mesmo de narrar a história da sua família, como se Alice estivesse sempre dizendo a Lurdes alguma coisa em tom menor e, por isso mesmo, de maneira pouco audível; coisas ditas para não serem plenamente escutadas.

Vista deste ângulo, a comensalidade implicava um silenciamento tão imposto quanto ativamente buscado, deixando apenas pequenas brechas para a circulação dos ruídos toleráveis. Ainda que não saiba a frase exata dita por Alice, sei que sinalizou ao seu filho que depois falariam sobre o assunto. O momento não era apropriado. Os olhares que trocamos nesse ínterim rapidamente ficaram para trás. Voltamos a comer lasanha e a conversar sobre amenidades. O silenciamento da criança tem menos a ver com o soprar de um vento infeliz do que com uma atitude conciliatória, um esforço para evitar que versões opostas sobre estupros colidissem e impossibilitassem a comensalidade. O que as feições de Alice mais guardavam do que contavam era que Ivan talvez tivesse estuprado apenas uma das suas filhas porque a outra parecia demais com ele; que ninguém da família o deixava sozinho com as crianças; que a irmã de Lurdes que fora estuprada contou para todos o que viveu, mas foi silenciada pela sua mãe; que Alice e suas primas, quando crianças, não gostavam de sentar no colo do tio, porque de um modo ou outro imaginavam o que ele poderia fazer.

A atitude conciliatória de Alice soldava como podia uma fratura geracional. Este aspecto sociológico da fratura somente se tornou evidente para mim quando percebi que minha interlocutora conversava comigo mobilizando diversos símbolos de juventude, tais como festas, cerveja e mesmo o vanguardismo das atitudes "descoladas". A identificação etária produziu tanto a possibilidade de eu contar para Alice sobre os machismos do seu tio, precisamente sobre as referências que ele fazia a mulheres como "pratos de comida" - ora "quentes" e saborosos, ora "frios" e indesejáveis -, quanto de ela me contar o que Lurdes jamais me dissera: que Ivan havia estuprado uma das suas irmãs. 
Creio que eu e Alice pertencemos a uma geração que vem sendo ensinada que estupros podem ser combatidos através da enunciação, a considerar pela disseminação de campanhas como "\#metoo"11 e pelas passeatas em que vítimas narram as violências sexuais que sofreram. Não tenho dificuldades de imaginá-la dando suporte político a causas e a eventos vinculados às pautas feministas, mas tenho dificuldade de vê-la enunciando em público os estupros praticados por seu tio. Minha impressão é a de que, já que as estratégias de combate ao estupro por ela acionadas derivavam da não aceitação totalizante do mandato de silenciamento, era necessário encontrar os espaços onde a enunciação da violência sexual não colidisse com a narrativa de injustiça de Lurdes e seu irmão. O aspecto arbitrário do mandato revela-se neste caso através de uma negação da reprodução do silêncio em toda e qualquer circunstância e da aceitação do valor deste último nas situações de comensalidade. A fratura geracional não é uma cisão absoluta, mas sim um corte sociológico que carrega o peso de uma demanda herdada que, ao se reproduzir, perde algumas das suas texturas mais essenciais.

Alice mimetizava o silêncio de Lurdes sem manifestar qualquer interesse pelo arrependimento de Ivan, isto é, ela performatizava em nome da sua mãe um silêncio que facultava a criação de um espaço para a enunciação do enquadramento religioso que fazia do seu tio um arrependido, ainda que nele não acreditasse. Se havia algo consciente no seu esforço para culpabilizar o tio, talvez houvesse também algo inconsciente no apego que a fazia voltar-se para sua mãe apresentando-se conciliada com Ivan, e a voltar-se para Ivan performatizando a relação dele com Lurdes. Através dos silêncios e das construções desse homem como um personagem bíblico, facultava-se ainda uma chance para o reconhecimento dele como um arrimo de família, alguém que propiciou a vinda da família para o Rio de Janeiro décadas atrás e, mais do que isso, retirou a própria mãe de um ciclo de violência encabeçado pelo pai; não somente porque ela estava submetida à violência física, mas também porque, suspeitava Alice, seu avô teria matado o primeiro marido da sua avó - história que ela não conhecia bem.

Há algo que se perde na comunicação, que não se completa, mesmo quando desejamos genuinamente responder a uma demanda que nos interpela. Se o compartilhamento intersubjetivo tem limites, se aquilo que uma geração anterior demanda nunca se reduz exatamente à percepção que a geração posterior consegue forjar a respeito do que foi demandado, a sensação de não reconhecimento é parte do reconhecimento, parte do processo de transmissão dos mandatos. 
Diria que o reconhecimento que Alice ofertava a Lurdes calando-se e Lurdes a Ivan também calando-se - mas por outras razões - era apenas o não reconhecimento que eles podiam suportar (Berlant 2010). ${ }^{12}$

\section{A plasticidade da violência e a ambivalência das relações}

Pouco antes de irmos olhar liquidificadores numa loja do shopping onde estávamos, Lurdes ligou para o seu irmão e requisitou que ele fosse ao nosso encontro. Ivan, mesmo sem investir firmemente numa leitura de si enquanto Jonas, assentia às associações propostas por ela. Ainda que o foco na conversão religiosa permitisse que esses irmãos cultivassem a perspectiva segundo a qual o presente pode ser separado do passado, a narrativa de Ivan dificultava a construção de uma masculinidade regenerada. Assim que sua irmã foi embora, ele me deu a entender que era responsável pelo que havia vivido e estava vivendo. Sua fala perpassava a violência dirigida contra a sua então esposa - a considerar pelo episódio em que Tuane o xingou de "veado" em público, coisa que "homem não admite" e demanda retaliação. No meio da briga, depois de apanhar, ela correu para uma delegacia. Ele foi atrás. Lá, terminou preso. Não por causa do conflito, mas em função de uma denúncia de homicídio que não foi adiante.

Ivan afirmou que era/foi policial e que Tuane, no mesmo dia em que foi à delegacia para denunciá-lo, se "arrependeu" e levou comida para ele. Contou também que permaneceu casado porque estava esperando que a sua filha fizesse 2 anos. A relação perdurou. Sua esposa, porém, foi ficando "largada", e outras mulheres não paravam de se oferecer a ele como "prato de comida quentinho". Bater em Tuane e traí-la foi para Ivan o mesmo que criar o "inimigo" dentro de casa. Dias antes de acusar seu marido de ter estuprado a própria filha, Tuane soube que ele estava saindo com outra mulher e que pediria a separação. Ouvi o final dessa narrativa religiosa sobre a responsabilidade masculina pela vingança feminina andando até a praça de alimentação, onde paguei um hambúrguer para Ivan - momento em que, já não recordo bem, a criança, hoje uma jovem, que ele teria estuprado lhe telefonou ou ele telefonou para ela: "papai está com saudade, filha!".

Ao passo que a transformação narrativa de mulheres em alimentos pode ser pensada como um processo metafórico de sexualização (o ato de comer sendo o ato de foder) e de animalização (a comida sendo a presa), a comensalidade aparece integrada à violência (Feldman 2002). Conversar com Ivan implicava ser movido para dentro da zona nublada onde as fronteiras entre os símbolos da violência e as violências concretas eram 
porosas, mais conectavam do que distinguiam os tapas por ele admitidos, os estupros que negou e as palavras machistas que declarou. Nos seus relatos, a masculinidade disposta ao coito era aquela que, se não violava sexualmente, violentava com socos e agressões verbais. Ivan encontrava respaldo para a sua fala no meu silêncio, espaço suficiente para a reprodução do prazer que ele sentia ao falar sobre as mulheres a serem comidas e ao comer alimentos reais.

Nunca consegui saber se ele dizia o que dizia porque via em mim semelhante disponibilidade ao sexo, ainda que direcionada a homens e não a mulheres, ou se enunciava a sua virilidade para me erotizar como presa. Se, por um lado, é legítimo dizer que a minha sexualidade operava nesse contexto facultando estas duas possibilidades interpretativas, não sendo necessário optar por uma ou outra, por outro lado, é importante considerar que essa imagem bem acabada do predador provinha também do meu desconforto, de uma sensibilidade que Ivan parecia perceber; creio que a ponto de saber que era crucial envelopar aquela situação de comensalidade com referências afetivas à sua filha e declarações de saudade. O predador que ele reconhecia em si mesmo e que fazia questão de me apresentar sempre soube diferenciar cria de presa e hoje, mais do que nunca, sabia diferenciar afeto de violência.

O fato de Ivan deixar tão visíveis as diferentes formas de violência que praticava, algumas por ele mesmo reconhecidas e outras profundamente naturalizadas, diz sobre uma masculinidade que quer ser reconhecida como viril, mas não quer que estupros sejam encarados como o resultado último do machismo. Essa dissociação entre machismo e violência está vinculada à banalização da referência a mulheres como pratos de comida e à veemente negação da disposição ao coito forçado, afinal, os estupradores são os outros. Justamente porque o repertório de gênero evocado por Ivan é normativo, chamo a atenção para o risco de tomarmos a masculinidade atuada por ele como um modelo privilegiado para a descrição da figura do estuprador e ainda para o risco de estabilizarmos etnograficamente uma única masculinidade em homens de carne e osso, como se as performances de gênero não variassem conforme os contextos e as pessoas em interação.

Vale lembrar que Ivan também é uma masculinidade provedora a quem alguns querem ofertar reconhecimento e que, se as masculinidades viris estupram, também o fazem as masculinidades cavalheirescas, injustiçadas e/ou moribundas. O ponto é que, em face de cada uma delas, se performatizadas por homens conhecidos ou não, se doentes ou não, se vivos ou mortos, se causaram prejuízos que julgamos toleráveis ou não, as nossas sensibilidades e disposições éticas, bem como as dos(as) nossos(as) interlocutores(as), variam e isto tem de ser levado em consideração para 
que a análise das relações de gênero não incorra em tipologizações que perdem o lastro no contexto da vida ordinária, isto é, aposte mais na rigidez dos modelos do que nas relações tal como vividas.

A centralidade da relacionalidade neste artigo culminou em descrições sobre o que acontece quando as vidas marcadas pelo acontecimento da violência sexual, a duras penas, seguem em frente. Esta preocupação me levou a não restringir a análise à relação entre masculinidades e violência e a jogar luzes sobre as maneiras como as relações de gênero de modo mais amplo incorporam e transformam os sentidos e os efeitos de estupros, práticas de cuidado, perdões e silêncios. Se pude perceber algo, é que aos sentimentos "atuais" das(os) minhas(meus) interlocutores acoplavam-se as violências passadas. Quando Lilian respondia ao chamado do seu pai evocando o perdão e restringindo o ressentimento, ela estava em contato com a violência sexual à qual fora submetida. Já o tecido relacional habitado por Alice, Lurdes e Ivan evidencia que, por mais que se tente, as violências não podem ser plenamente deixadas no passado, já que o passado nunca termina de passar. Estou sugerindo pensarmos que as violências são plásticas: como não conhecem formas fixas, deslizam no interior dos tecidos relacionais sempre em direção ao atual, precisamente em direção aos sentimentos, às demandas e às urgências que nascem no presente. Evito a metáfora do vento evocada por Cho (2008) porque, embora esteja falando sobre algo que sopra do passado em direção ao futuro, busquei expandir as formas assumidas pela violência para além do trauma. Enquadrá-la somente nessa categoria seria o mesmo que empalidecer a sua plasticidade. Penso na maleabilidade necessária à capacidade das mais variadas violências de se infiltrarem e florescerem até mesmo nos afetos aos quais costumamos atribuir valor moral positivo.

Considerando que o perdão é um desses sentimentos, algumas ressalvas devem ser feitas. A mais geral é a de que descrever o perdão como uma resposta interpessoal possível não é o mesmo que idealizá-lo como norma, nem inventá-lo como solução para as violências. Ao contrário, venho defendendo que esse sentimento é inseparável das violências passadas, pois ele as transporta para o presente ao mesmo tempo em que fornece algum alívio àqueles que algo sofreram. Essa ênfase na relação entre os sentimentos atuais e as violências de outrora me parece fundamental à demonstração de que existem vivências que não necessariamente transcendem o abuso e, mais ainda, à fomentação da crítica à ideia de que haveria um eu inteiriço e anterior ao dano ao qual se poderia voltar ou que poderia ser integralmente recuperado. Tenho Lilian em mente quando penso que a forma de afastamento que ela procurava em relação ao dano, a evocação 
do perdão, era violenta e, ainda assim, potente o bastante para não permitir que o dano causado por Edson se tornasse a totalidade da vida dela. Uma vez que a violência é plástica, tão destrutiva quanto uma forma de vida, ela desmantela as pessoas ao mesmo tempo em que habilita formas de viração. $\mathrm{O}$ cuidado, o perdão e o silêncio são práticas afetivo-morais, pesos e alívios que as minhas interlocutoras carregavam e sentiam enquanto teciam relações em almoços difíceis de serem digeridos e/ou lutavam contra laudos psicológicos que impulsionavam a punição estatal.

A conciliação fraturada é uma resposta à pergunta sobre como o mundo comum é ameaçado, desfeito e reparado sem que sejam apagadas as memórias conscientes e inconscientes do que foi vivido junto. Visto que a noção de memória como prática moral enfatiza os enquadramentos conscientes das lembranças e a noção de mandato está mais voltada às transmissões inconscientes, torno a sinalizar que essas memórias chegam ao presente mediadas pelos enquadramentos disponíveis no tempo atual e pelas urgências relacionais que lhes são próprias, ora perdoar pai que deveria ter sido um herói, ora tolerar o tio considerado "pedófilo" e "machista". Os tipos de conciliação fraturada a que fiz referência derivavam da combinação de elaborações simbólicas, intersubjetivas e intrapsíquicas dificilmente distinguíveis umas das outras no fluxo da vida ordinária.

Os dois casos apresentados apontam para formas de vida específicas, mas juntos fornecem elementos que caracterizam a ambivalência como marca principal das fraturas relacionais que, se encontravam alguma resolução, não deixavam de incomodar conforme a vida avançava com as suas durezas. Aprender a conviver com homens que causaram danos inestimáveis e/ou cuja presença em situação de proximidade promovia desconforto requeria não apenas a produção da capacidade de tolerá-los, mas também o aprendizado de como suportar subjetivamente os sentimentos que se opõem (amor e ódio, no exemplo clássico) com intensidades variadas na partilha do dia a dia. Se há vitalidade quando uma filha efetiva uma conduta de cuidado em relação ao pai que a estuprou, há também dor, falência, sensação de exaustão, desgosto provocado pela reiteração da conduta que, em dado momento do tempo, foi considerada virtuosa. Recorro à palavra ambivalência para caracterizar a conciliação fraturada com a esperança de assim oferecer uma imagem das relações que não dissolva a "complicação" que comportam.

Recebido em: 19 de julho de 2020.

Aprovado em 14 de outubro de 2020 


\section{Everton Rangel}

Doutor em Antropologia Social pelo Programa de Pós-Graduação em Antropologia Social do Museu Nacional da Universidade Federal do Rio de Janeiro (PPGAS/MN/UFRJ). Integra o Núcleo de Estudos em Corpos, Gênero e Sexualidades (NuSEX) do Museu Nacional e o Laboratório de Antropologia do Estado, regulação e políticas públicas (Documenta) do Programa de Pósgraduação em Sociologia e Antropologia do Instituto de Filosofia e Ciências Sociais (IFCS/UFRJ). Realizou pesquisa sobre corrupção para a Topos Partnership / Open Society Foudations (OSF). Seus principais interesses de pesquisa são: gênero, raça, sexualidade, família, interseccionalidade, violência, ética ordinária, práticas políticas e antropologia do Estado.

https://orcid.org/0000-0002-1819-3432

Email: era.rangel@gmail.com

\section{Notas}

1 Para proteger a identidade dos meus interlocutores, optei por usar nomes fictícios.

2 Utilizo o termo casa para destacar que faço referência a violências que, porque sucederam nessa localização específica, dizem algo sobre dinâmicas relacionais anteriores e posteriores ao dano - às quais raramente pesquisadores têm acesso. O próprio fato de $75,9 \%$ das ocorrências registradas pelas polícias brasileiras entre 2017 e 2018 terem sido cometidas por conhecidos das vítimas (Fórum Brasileiro de Segurança Pública 2019) reforça a relevância do foco nas famílias e nas casas. Nesse sentido, este artigo aponta para o lugar crítico da casa na compreensão tanto das dinâmicas afetivo-morais de regulação e gestão da violência quanto dos processos de produção de pessoas e famílias. Trata-se de um apontamento que espero em outro momento desdobrar perguntando-me sobre quais são as formas individuais e coletivas de se virar para fazer dinheiro e organizar despesas quando sobre os condenados e os seus próximos recai o peso do estigma e da suspeição. Faço essas considerações visando, por um lado, assinalar a amplitude de temas relacionados à presença do estuprador dentro de casa, desde temas ligados à subjetividade àqueles que dizem respeito às práticas econômicas; e, por outro lado, visando salientar a importância de não separarmos a vida em esferas: a violência, a moralidade, o afeto, o econômico etc. A minha argumentação, neste artigo, gira em torno da descrição do modo como as violências de outrora se vinculam aos afetos demandados no presente. Em pesquisa futura, espero "complicar" essas descrições voltando-me mais diretamente ao lugar do sustento no interior das relações e das casas afetadas por crimes sexuais. Para um balanço bibliográfico da discussão sobre casa, ver Thomas Jacques Cortado (2020). 
3 "Art. $1^{\circ}$ A execução penal tem por objetivo efetivar as disposições de sentença ou decisão criminal e proporcionar condições para a harmônica integração social do condenado e do internado" (Brasil 1984).

4 "O processo de conhecimento é a fase em que ocorre toda a produção de provas, a oitiva das partes e testemunhas, dando conhecimento dos fatos ao juiz responsável, a fim de que este possa aplicar corretamente o direito ao caso concreto, com o proferimento da sentença" ("Processo..." 2019).

5 Para uma análise da minha própria desconfiança em relação à narrativa de injustiça de um interlocutor, ver Rangel (2019). Para uma análise mais geral sobre a minha posição em campo e as estratégias narrativas que aciono, ver Rangel (2020).

6 Em poucas palavras, a melancolia costuma ser associada à perda de um objeto que não necessariamente deixou de existir, mas que foi perdido enquanto objeto de amor. Em outros casos, trata-se de uma perda que se quer compreendida como tal, mas que se investe no sujeito e o conforma - como quando se sabe que uma pessoa morreu, mas não se sabe exatamente o que dessa pessoa foi perdido. Em contrapartida, no trabalho de luto, o objeto perdido é reconhecido e o esvaziamento do mundo provocado pela perda é incorporado no sujeito, que se transforma a partir de um processo doloroso, mas menos soturno que o melancólico. Ver Freud (2011) para elaborações mais detidas desses conceitos. Ver Butler para uma apropriação contemporânea, política e coletiva do trabalho de luto e sua relação com a noção de vulnerabilidade (2004).

7 No original: “¿El perdón debe entonces tapar el agujero? ¿Debe suturar la herida en un proceso de reconciliación? ¿O bien dar lugar a otra paz, sin olvido, sin amnistía, fusión o confusión? Por supuesto, nadie se atrevería decentemente a objetar el imperativo de la reconciliación, esta reconstitución de una salud o de una "normalidad", por necesarias y deseables que puedan parecer a través de las amnesias, el 'trabajo de duelo', etc. Un perdón 'finalizado' no es un perdón, es solo una estrategia política o una economía psicoterapéutica".

8 No original: "Una comisión o un gobierno no puede perdonar. Sólo yo, eventualmente, podría hacerlo. (And I am not ready to forgive.) Y no estoy dispuesta a perdonar - o lista para perdonar".

9 No original: "what a better place to burry a social trauma than in the closely guarded space of the family?".

10 Teixeira (2011), ao debruçar-se sobre a categoria "ex-bandido", interessante até certo ponto para pensar o caso de Ivan, argumenta que para os seus interlocutores a conversão religiosa é um processo que diz respeito a uma "metamorfose subjetiva" que nunca se encerra. Desloca-se do mundo do crime em direção às igrejas, mas a memória da vida anterior permanece presente nos corpos, nos movimentos, nas maneiras como se segura a Bíblia, ainda que existam esforços contundentes de "esquecimento" dessa memória incorporada. A batalha espiritual seria incessante. 
11 Movimento contra o assédio sexual e a violência sexual que, através das plataformas de interação on-line, alcançou popularidade global. Estão vinculadas à "\#metoo" as denúncias de assédio, estupro e agressões sexuais de mais de oitenta mulheres da indústria cinematográfica norte-americana contra Harvey Weinstein. Na página dele na Wikipédia ("Harvey..." 2020), classifica-se como "efeito Weinstein" denúncias similares a homens poderosos em todo o mundo.

12 No original, "recognition is the misrecognition you can bear" (Berlant 2010:96).

\section{Referências bibliográficas}

BERLANT, Lauren. 2010. "Cruel Optimism". In: Gregory J. Seigworth \& Melissa Gregg, The affect theory reader. Duke: Duke University Press. pp. 93-117.

BRASIL. Lei $\mathrm{n}^{0} 7.210$, de 11 de julho de 1984. Institui a Lei de Execução Penal. Brasília: Presidência da República [s. d.]. Disponível em: http://www. planalto.gov.br/ccivil_03/leis/17210. $\underline{\text { htm. }}$. Acesso em 21/10/2020.

BUTLER, Judith. 2004. Precarious Life: the powers of mourning and violence. London/NY: Verso.

CADUFF, Carlo. 2019. "Hot Chocolate". Critical Inquiry, v. 45, n. 3:787-803.

CARSTEN, Janet. 2004. After kinship. Cambridge: Cambridge University Press.

CHO, Grace M. 2008. Haunting the Korea diaspora: shame, secrecy, and the forgotten war. Minnesota: University of Minnesota Press.

CORTADO, Thomas Jacques. 2020. "House". In: Anthropen. org. Edições de arquivos contemporâneos: Paris. Disponível em: https://www.anthropen.org/voir/ Maison?fbclid = IwAR0I07FqTy5M
1JqcSuHJNZFNnA8mS33kQQ5O DuBr2-rDErvZSA3qWRXUpGA\#. Xp8YHyMS65Q.facebook. Acesso em 21/10/2020.

DAS, Veena. 2018. "Ethics, selfknowledge, and life taken as a whole". HAU: Journal of Ethnographic Theory, v. 8, n. 3:537-549.

DERRIDA, Jacques. 2003. El siglo y el perdón: fe y saber. Buenos Aires: Ediciones de La Flor.

DERRIDA, Jacques. 2005. "O perdão, a verdade, a reconciliação: qual gênero?". In: Evando Nascimento (org.), Jacques Derrida: pensar a desconstrução. São Paulo: Estação da Liberdade. pp. 45-92.

DUARTE, Luiz Fernando Dias. 2011. "Geração, fratria e gênero: um estudo de mandato transgeracional e subjetivação diferencial". Trivium, v. 3, n. 1:p. 1-19.

ELIAS, Norbert. 2001. A solidão dos moribundos. Rio de Janeiro: Jorge Zahar Editor.

FELDMAN, Allen. 2002. "Strange Fruit: The South-African Truth Commision and the Demonic Economies of Violence". In: Bruce Kapferer (ed.), 
Beyond Rationalism: Rethinking magic, witchcraft and sorcery. NY/ Oxford: Berghahn Books. pp. 234-265 FREUD, Sigmund. 2011. Luto e Melancolia. São Paulo: Cosac Naify. FÓ R U M B R A S I L E IRO D E SEGURANÇA PÚBLICA. 2019. Anuário de Segurança Pública Ano 13. Coordenação de Samira Bueno e Renato Sérgio de Lima. Brasília.

GRISWOLD， Charles L. 2007. Forgiveness: a philosophical exploration. Cambridge: Cambridge University Press.

HARVEY Weinstein. 2020. In: WIKIPÉDIA: a enciclopédia livre [San Francisco, CA: Wikimedia Foundation, 2020]. Disponível em: https://pt.wikipedia.org/wiki/ Harvey_Weinstein. Acesso em 21/01/2020.

HOCHSCHILD, Arlie Russel. 2013. "Trabalho emocional, regras de sentimento e estrutura social". In: Maria Claudia Coelho (org.), Estudos sobre interação: textos escolhidos. Rio de Janeiro: EdUERJ. pp. 169-209.

LAGO, Natalia. 2019. Jornadas de visita e luta: tensões, relações e movimentos de familiares nos arredores da prisão. Tese de Doutorado Antropologia, Faculdade de Filosofia, Letras e Ciências Humanas, Universidade de São Paulo.

LAMBEK, Michael. 1996. "The past imperfect: remembering as moral practice". In: Paul ANTZE \& Michael LAMBEK (eds.), Tense past: cultural essays in trauma and memory. London: Routledge. pp. 235-254.

MACHADO, Lia Zanotta. 1998. "Masculinidade, sexualidade e estupro: as construções da virilidade". Cadernos Pagu, n. 11:231-273.
MARGALIT, Avishai. 2004. The ethics of memory. Cambridge, MA: Harvard University Press.

PROCESSO de conhecimento Novo CPC (Lei $\mathrm{n}^{\circ}$ 13.105/15). In: Dicionário Jurídico DireitoNet [on-line]. Disponível em: https://www.direitonet.com.br/ dicionario/exibir/1064/Processode-conhecimento-Novo-CPC-Leino-13105-15. Acesso em 21/10/2020.

RANGEL, Everton. 2019. "O mal e os amores difíceis: tecidos relacionais habitados por homens condenados por estupro de vulnerável e mulheres a eles vinculadas". Revista Anthropológicas, v. 30, n. 1:5-37. . 2020. Depois do Estupro. Homens condenados e seus tecidos relacionais. Tese de Doutorado em Antropologia Social, Museu Nacional, Universidade Federal do Rio de Janeiro.

REZENDE, Claudia Barcellos \& COELHO, Maria Claudia. 2010. Antropologia das Emoções. Rio de Janeiro: FGV.

SEGATO, Rita. 2003. Las estructuras elementales de la violencia: ensayos sobre género entre la antropología, el psicoanálisis y los derechos humanos. Bernal: Universidad de Quilmes.

TEIXEIRA, Cesar Pinheiro. 2011. A construção social do "ex-bandido": um estudo sobre sujeição criminal e pentecostalismo. Rio de Janeiro: 7Letras.

WEITZ, Eric D. 2005. "Review of Margalit Avishai: The ethics of memory". In: $H$-Net Reviews. Disponível em: https://www.h-net.org/reviews/ showrev.php?id=19012. Acesso em 01/12/2020. 


\section{CONCILIAÇÃO FRATURADA - QUANDO O “ESTUPRADOR" ESTÁ DENTRO DE CASA}

\section{FRACTURED CONCILIATION - WHEN THE “RAPIST" IS IN THE HOME}

Resumo

A pergunta mais abrangente deste artigo é: o que implica levar a vida com homens condenados por crimes sexuais para as mulheres que com eles compartem laços afetivos, partilham os dias e trabalham para tornar essa vida viável? Descrevendo as assimetrias e as desigualdades das relações de gênero a partir dos modos afetivo-morais como as minhas interlocutoras respondiam a elas, busco desenvolver o que chamei de conciliação fraturada. Trato de formas de vida que emergem quando fraturas relacionais desencadeadas pelo estupro existem, mas são conciliadas: quando o pai - severamente adoecido - é o violador da filha que, em face do sofrimento dele, se esforça para perdoar o que considera (im)perdoável; e quando almoços de família incluem o tio que é reconhecido pela sua sobrinha como pedófilo, mas por ela é tolerado em função do amor que a irmã dele, mãe dela, sente por seu irmão.

Palavras-chave: Família, Estupro, Emoções, Gênero, Fratura.

\section{Abstract}

This article asks what implications there are for women who live with men convicted of sexual crimes sharing not only affective ties with them, but also working to make this life viable. By describing the asymmetries and inequalities of gender relations through the affective-moral ways my women interlocutors responded to them, I develop what I called 'fractured conciliation'. I deal with forms of life that emerge when there are relational fractures triggered by rape, but are reconciled: when the father - severely ill - is the rapist of his daughter, and she, faced with his suffering, strives to forgive the unforgivable; and when family lunches include the uncle who is recognized by his niece as a "pedophile", but is tolerated by her because of the love his sister, her mother, feels for her brother. Key words: Family, Rape, Emotions, Gender, Fracture. 


\section{CONCILIACIÓN FRACTURADA \\ - CUANDO EL VIOLADOR SE \\ ENCUENTRA DENTRO DE CASA}

\section{Resumen}

La pregunta más amplia de este artículo es: ¿̇en qué implica vivir con hombres condenados por delitos sexuales para las mujeres que comparten lazos emocionales y el día a día con ellos, así como también trabajan para que esta vida sea viable? Al describir las formas morales y afectivas que mis interlocutoras usaban para responder a las asimetrías y desigualdades de las relaciones de género, busco desarrollar lo que llamé de conciliación fracturada. Se trata de formas de vida que surgen cuando hay fracturas relacionales provocadas por la violación, pero que se reconcilian: cuando el padre, gravemente enfermo, es el violador de su hija y ella, ante el sufrimiento de él, trata de perdonar lo imperdonable; y cuando los almuerzos familiares incluyen al tío, a quien su sobrina reconoce como un pedófilo, pero a quien ella tolera en nombre del amor que su madre siente por este hombre.

Palabras clave: Familia, Violación, Emociones, Género, Fractura. 